\section{RSP}

http://www.rsp.fsp.usp.br/
Revista de Saúde Pública

\title{
Factors associated with low birthweight: a case-control study in a city of Minas Gerais
}

\author{
Érica Cesário Defilipo' (iD, Paula Silva de Carvalho Chagas" (iD, Andreia Peraro-Nascimento"II iD, \\ Luiz Cláudio Ribeiro ${ }^{\mathrm{IV}}$ \\ I Universidade Federal de Juiz de Fora campus Governador Valadares. Instituto de Ciências da Vida. \\ Departamento de Fisioterapia. Governador Valadares, MG, Brasil \\ " Universidade Federal de Juiz de Fora. Faculdade de Fisioterapia. Programa de Pós-graduação em Ciências da \\ Reabilitação e Desempenho Físico-funcional. Juiz de Fora, MG, Brasil \\ III Universidade Federal de Juiz de Fora campus Governador Valadares. Instituto de Ciências da Vida. \\ Departamento de Farmácia. Governador Valadares, MG, Brasil \\ Iv Universidade Federal de Juiz de Fora. Departamento de Estatística. Programa de Pós-Graduação em Saúde \\ Coletiva. Juiz de Fora, MG, Brasil
}

Correspondence:

Érica Cesário Defilipo

Clínica Escola de Fisioterapia

Rua Leonardo Cristino, 3.400

35012-000 Governador Valadares, MG, Brasil

E-mail: erica.defilipo@ufjf.edu.br

Received: Sep 5, 2019

Approved: Out 29, 2019

How to cite: Defilipo EC, Chagas PSC, Peraro-Nascimento A, Ribeiro LC. Factors associated with low birthweight: a case-control study in a city of Minas Gerais. Rev Saude Publica. 2020:54:71.

Copyright: This is an open-access article distributed under the terms of the Creative Commons Attribution License, which permits unrestricted use, distribution, and reproduction in any medium, provided that the original author and source are credited.

\section{ABSTRACT}

OBJECTIVE: To analyze the many factors regarding socioeconomic and healthcare-related variables linked to maternal diseases and the possible impact of the environmental disaster of Mariana, given the prenatal exposure to different water sources for human consumption that were associated with low birthweight in full-term live births in the Municipal Hospital of Governador Valadares, Minas Gerais.

METHODS: Case-control study, carried out with live births at the Municipal Hospital of Governador Valadares, from May 2017 to July 2018. The case group consisted of full-term live births and low birthweight, and the control group consisted of full-term live births with adequate weight, matched by gender and date of birth. For each case, two controls were selected. Data collection was performed through interviews with the puerperal women, and complementary information was obtained by analyzing the prenatal card and medical records. For data analysis, logistic regression was performed.

RESULTS: The study included 65 live births from the case group and 130 from the control group. After the analysis was adjusted for other factors under study, we found that the higher risks of low birthweight are associated with the first childbirth $(\mathrm{OR}=2.033 ; 95 \% \mathrm{CI}=1.047-3.948 ; \mathrm{p}=0.036)$, smoking during pregnancy $(\mathrm{OR}=2.850 ; 95 \% \mathrm{CI}=1.013-8.021 ; \mathrm{p}=0.047)$ and consumption of water supplied by the municipalities affected by the tailings from the Fundão dam failure $(\mathrm{RC}=2.444 ; 95 \% \mathrm{CI}=1.203-4.965 ; \mathrm{p}=0.013)$.

CONCLUSIONS: The variables "water consumed during pregnancy," "previous pregnancies" and "maternal smoking" were associated with low birthweight in the population studied. The importance of epidemiological studies that assess water quality and its adverse health effects is reinforced, as well as greater prenatal control of first-time pregnant women and greater support of policies against smoking, especially during pregnancy.

DESCRIPTORS: Low Birth Weight Infant. Risk Factors. Environmental Exposure. Socioeconomic Factors. Case Studies and Controls. Maternal and Child Health 


\section{INTRODUCTION}

Each year more than twenty million children with low birthweight are born worldwide, which is defined as weighing less than $2.5 \mathrm{~kg}^{1,2}$. Low birthweight is considered an important risk marker for infant mortality, besides contributing to morbidities such as infectious diseases, cognitive and neurological dysfunctions, developmental delay and greater probability of developing chronic diseases ${ }^{3}$.

Low birthweight rates in Brazil, considering the analysis of the period from 1996 to 2011, show stability of about $8 \%$. When analyzing regionality, highest rates were found in the most developed regions, Southern and Southeastern, and a significant increase was observed in the less developed regions, North, Northeast and Midwest ${ }^{4}$. The reasons for the increase in these rates, considering the improvement of social and maternal and child health indicators in recent years, are not well-known ${ }^{5}$.

Low birthweight is considered a complex public health problem due to its multifactorial etiology. A review study on low birthweight in the Americas showed that most studies published recently agree with the association of sociodemographic, biological and behavioral factors. Studies that refer to the association of low birthweight with environmental risk factors, such as exposure to air, water or soil pollution, are gaining importance ${ }^{1}$.

The association of low birthweight with air pollution has been reported in the literature ${ }^{1,6}$, but few studies have evaluated the relationship of this outcome with water quality. In view of the socioenvironmental tragedies that occurred in Minas Gerais, such as the Fundão dam failure in Mariana, research is needed to assess water quality and its adverse health effects. At some stages of life, the damage caused to health by pollution can be irreversible. This situation becomes more serious when we refer to maternal and child health, due to the interference in reproduction and gestational and living conditions of the infant ${ }^{7}$.

This study aimed to analyze the many factors regarding socioeconomic and healthcare-related variables linked to maternal diseases and the possible impact of the environmental disaster that took place in Mariana, given the prenatal exposure to different water sources for human consumption that were associated with low birthweight in full-term live births in the Municipal Hospital of Governador Valadares, Minas Gerais.

\section{METHODS}

Case-control study carried out with live births at the Municipal Hospital of Governador Valadares, from May 2017 to July 2018. This hospital was chosen as it is linked to the Brazilian Unified Health System and it is the only one with a neonatal intensive care unit in the region, considered a reference for the cities of the Rio Doce Valley. Cases were considered live births at term, with gestational age equal to or greater than 37 weeks and less than 42 weeks and weighing less than 2,500 grams (low birthweight), while the controls were full-term live births weighing 2,500 grams or more (adequate birthweight), matched by gender and date of birth. For each case, two controls were selected. Live births with congenital malformations, genetic syndromes, progressive diseases and lesions of the nervous system, diagnosed or suspected at birth, were excluded from the study. When there were more than two newborns who met the inclusion criteria, choosing was random. When there were no two controls for pairing, the case was not included in the study.

Data collection was performed through structured interviews with the puerperal women, still during hospitalization, within 24 to 48 hours after delivery. Complementary information was obtained by analyzing the prenatal card and the records of the puerperal mother and newborn. Data were collected by previously trained researchers. 
Low birthweight was considered as a dependent variable. The independent variables were organized into five blocks, according to the explanatory model presented in Figure, which contains the categorization form of each variable studied. To analyze the variable "water consumed during pregnancy," the fact that the participants lived in different municipalities was considered; while some were affected by the tailings from the Fundão dam failure, others were not. For this reason, this variable was categorized into 1) mineral water, supplied from mines, wells or cisterns or from the water supply service of municipalities not affected by mud; and 2) water from the supply service of the affected municipalities. The categorization of the variables "number of prenatal appointments" and "first prenatal appointment" was defined based on the one proposed by the Ministry of Health, which determines the beginning of prenatal care up to the sixteenth week of gestation and a minimum of six appointments ${ }^{8}$. The variable "number of appointments" was categorized according to what would be recommended (six appointments or more) or not recommended (less than six appointments) and the variable "first prenatal appointment" was categorized as up to 16 weeks and more than 16 weeks $^{9}$ (Figure). Alcohol dependence was detected using the CAGE questionnaire, considering as dependent women who presented at least one affirmative answer ${ }^{10}$.

Logistic regression analysis was used to verify the associations of independent variables with low birthweight. The associated factors that presented p-value below 0.20 in the bivariate analysis per block were considered eligible to compose the multivariate models. Logistic regression analysis was performed according to the order of entry: first the socioeconomic, demographic and environmental factors (block 1), followed by reproductive factors (block 2), behavioral factors (block 3), factors related to health care

Section 1

Section 2

tion 3

psychological or sexual violence (no; yes); stressful event during pregnancy, including family death, divorce or family discussion, serious illness, depression, or work-related problems (no; yes).

\section{$\sqrt{10}$}

Factors related to health care during prenatal care and childbirth

Section 4

Number of prenatal appointments ( $<6$ appointments; $\geq 6$ appointments); first prenatal appointment $(\leq 16$ weeks; $>16$ weeks);

institution that performed prenatal care (public; private); vaccination during pregnancy (no; yes or immunized); coverage by the Family Health Strategy at the place of residence (no; yes); and type of delivery (vaginal; cesarean section).

Factors related to maternal diseases

Section 5 Gestational diabetes, chronic diabetes, gestational hypertension, chronic hypertension, pre-eclampsia, eclampsia, urinary tract infection, self-reported vaginal bleeding in the first trimester of pregnancy, chorioamnionitis, toxoplasmosis, HIV/aids, early rupture of membranes, syphilis, anemia, malnutrition, obesity, oligohydramnios, dengue infections, Zika virus or Chikungunya and others (no; yes).

Figure. Explanatory model of the independent variables divided into blocks and order of input of the factors in the logistic regression analysis. 
during prenatal care and childbirth (block 4) and, finally, factors related to maternal diseases (block 5), according to Figure 1. The previously selected variables were submitted to the new multivariate analysis, using $\mathrm{p}$-value below 0.05 as a parameter for permanence in the final model. The research was approved by the Ethics and Research Committee on Human Beings (CAAE 61055716.4.0000.5147), being conducted within the required ethical standards.

\section{RESULTS}

The study included 65 live births belonging to the case group and 130 to the control group. We excluded a case of low birthweight with a diagnosis of genetic syndrome and 18 cases that did not have their respective controls. Nine puerperal women did not agree to participate.

Of the participant live births, 118 (60.5\%) had mothers living in Governador Valadares and $23(11.8 \%)$ in other eight neighboring municipalities that were also hit by the mud. The remaining 54 live births $(27.7 \%)$ had mothers who lived in neighboring municipalities not affected by the disaster.

There was a predominance of mineral water consumption during pregnancy (38.5\%), but $23 \%$ of the puerperal women consumed water from a well, mine or cistern while pregnant. The others consumed the water supplied by the municipality of Governador Valadares (14.9\%), from the other municipalities affected by mud (7.7\%) and unaffected municipalities (15.9\%). The only variable, among the socioeconomic, demographic and environmental factors, that presented a significant association with low birthweight in the bivariate analysis was "water consumed during pregnancy" $(p=0.008)$, as observed in Table 1.

Regarding reproductive factors, the variable "previous birth of underweight child" $(\mathrm{p}=0.065)$ presented $p<0.20$, as well as the variables "cigarette use" $(p=0.036)$ and "victim of violence against pregnant women" ( $p=0.140$ ), referring to behavioral factors (Table 2 ).

Only one puerperal woman, belonging to the case group, did not perform prenatal care and thus did not attend any appointment; three attended only one appointment and, in total, 45 puerperal women attended less than six appointment. As the sample would be insufficient for the analysis using groups with a smaller number of appointments, we chose to classify this variable into only two categories, as described above. In this section, referring to factors related to health care during prenatal care and childbirth, no variable presented a significant association with low birthweight (Table 3).

Finally, 145 puerperal women presented some form of maternal disease during pregnancy. In this section, the variables that presented $\mathrm{p}<0.20$ were selected: "urinary tract infection" $(\mathrm{p}=0.089)$ and "self-reported vaginal bleeding in the first trimester of pregnancy" $(\mathrm{p}=0.112)$, as shown in Table 4.

In the logistic regression analysis, the first introduced were variables "water consumed during pregnancy" (section 1) and "previous case of low birthweight" (section 2), both of which were maintained in the model. Then we introduced variables of section 3, "cigarette use" and "victim of violence against pregnant women," with later removal of the latter due to loss of significance. As section 4 did not present any variable with $p<0.20$, the variables of section 5 were added: "urinary tract infection" and "vaginal bleeding." These last two variables were also removed from the analysis because they did not present a significant association with low birthweight.

Table 5 shows the result of the final logistic regression model, which indicates they presented a significant association with low birthweight: first child (odds ratio $[\mathrm{OR}]=2.033 ; \mathrm{p}=0.036$ ), smoking during pregnancy $(\mathrm{OR}=2.850 ; \mathrm{p}=0.047)$ and water provided by the municipalities affected by the mud $(\mathrm{OR}=2.444 ; \mathrm{p}=0.013)$. 
Table 1. Number of cases and controls, odds ratio, $95 \%$ confidence interval and p-value for socioeconomic, demographic and environmental factors (section 1).

\begin{tabular}{|c|c|c|c|c|c|c|c|}
\hline \multirow[t]{2}{*}{ Variables } & \multicolumn{2}{|c|}{$\begin{array}{c}\text { Cases } \\
(n=65)\end{array}$} & \multicolumn{2}{|c|}{$\begin{array}{c}\text { Controls } \\
(n=130)\end{array}$} & \multirow[t]{2}{*}{ OR } & \multirow[t]{2}{*}{$95 \% \mathrm{Cl}$} & \multirow{2}{*}{$p$} \\
\hline & $\mathbf{n}$ & $\%$ & $\mathbf{n}$ & $\%$ & & & \\
\hline
\end{tabular}

Mother's schooling level

$\begin{array}{lllllllll}\text { Incomplete high school or under grade } & 32 & 49.2 & 63 & 48.5 & \text { Ref } & \\ \text { Complete high school or superior grade } & 33 & 50.8 & 67 & 51.5 & 0.970 & 0.535-1.759 & 0.919\end{array}$

Mother's age

$<20$ years or $\geq 35$ years

$\begin{array}{lllll}17 & 26.2 & 40 & 30.8 & \text { Ref }\end{array}$

20 to 34 years

$48 \quad 73.8 \quad 90$

69.21 .255

$0.644-2.445$

0.504

Mother's race

$\begin{array}{lccccccc}\text { White } & 11 & 16.9 & 18 & 13.8 & \text { Ref } & - \\ \text { Black or brown } & 54 & 83.1 & 112 & 86.2 & 0.789 & 0.348-1.787 & 0.569 \\ \text { Mother's marital status } & & & & & & & \\ \text { With a partner } & 49 & 75.4 & 101 & 77.7 & \text { Ref } & - \\ \text { Without partner } & 16 & 24.6 & 29 & 22.3 & 1.137 & 0.565-2.288 & 0.718\end{array}$

Monthly household income ${ }^{b}$

$\begin{array}{llllllll}\leq 2 \text { minimum wages } & 48 & 78.7 & 93 & 75.0 & \text { Ref } & - & \\ >2 \text { minimum wages } & 13 & 21.3 & 31 & 25.0 & 0.813 & 0.389-1.695 & 0.580\end{array}$

Mother's occupation

No paid occupation

$\begin{array}{lllll}42 & 64.6 \quad 84 & 64.6 \quad \text { Ref }\end{array}$

With paid occupation

$\begin{array}{lllll}23 & 35.4 & 46 & 35.4 & 1.000\end{array}$

$0.537-1.864$

1.000

Father's schooling level

Incomplete high school or under grade

Complete high school or superior grade

$\begin{array}{lllll}32 & 55.2 & 69 & 59.0 \quad \text { Ref }\end{array}$

Father's age

$<20$ years or $\geq 35$ years

$\begin{array}{lllll}15 & 24.2 & 37 & 28.7 & \text { Ref }\end{array}$

20 to 34 years

$\begin{array}{llllll}47 & 75.8 & 92 & 71.3 & 1.260 & 0.629-2.526\end{array}$

0.514

Father's race

$\begin{array}{lrrrrrrr}\text { White } & 18 & 27.7 & 32 & 24.6 & \text { Ref } & - \\ \text { Black, brown or yellow } & 47 & 72.3 & 98 & 75.4 & 0.853 & 0.435-1.673 & 0.643 \\ \text { Basic sanitation } & & & & & & & \\ \text { No } & 10 & 15.4 & 12 & 9.2 & \text { Ref } & - & \\ \text { Yes } & 55 & 84.6 & 118 & 90.8 & 0.559 & 0.228-1.373 & 0.200\end{array}$

Place of residence

$\begin{array}{lccccccc}\text { Urban } & 50 & 76.9 & 105 & 80.8 & \text { Ref } & - & \\ \text { Rural } & 15 & 23.1 & 25 & 19.2 & 1.260 & 0.611-2.597 & 0.531\end{array}$

Water consumed during pregnancy

Mineral, from mines, wells, cisterns

or the supply service of non-affected

municipalities

$\begin{array}{lllll}43 & 66.2 & 108 & 83.1 & \text { R }\end{array}$

Ref

$0.008^{a}$

Supply services of affected

municipalities

$22 \quad 33.8 \quad 22 \quad 16.9 \quad 2.512 \quad 1.262-5.00$

RC: odds ratio; $95 \% \mathrm{Cl}$ : 95\% confidence interval; $\mathrm{p}$-value: level of statistical significance; Ref: reference category a $\mathrm{p}<0.20$

b Some puerperal women did not know or did not agree to report the family's monthly income $(n=10)$, father's schooling level $(n=20)$ and father's age $(n=4)$, and these data were considered missing. 
Table 2. Number of cases and controls, odds ratio, 95\% confidence interval and p-value of reproductive (block 2) and behavioral (block 3) factors.

\begin{tabular}{|c|c|c|c|c|c|c|c|}
\hline \multirow[t]{2}{*}{ Variables } & \multicolumn{2}{|c|}{$\begin{array}{c}\text { Cases } \\
(\mathrm{n}=65)\end{array}$} & \multicolumn{2}{|c|}{$\begin{array}{l}\text { Controls } \\
(\mathrm{n}=130)\end{array}$} & \multirow[t]{2}{*}{ OR } & \multirow[t]{2}{*}{$95 \% \mathrm{Cl}$} & \multirow{2}{*}{$\mathbf{p}$} \\
\hline & $\mathbf{n}$ & $\%$ & $\mathbf{n}$ & $\%$ & & & \\
\hline \multicolumn{8}{|l|}{ Section 2} \\
\hline \multicolumn{8}{|c|}{ Interval between pregnancies } \\
\hline$\leq 2$ years & 5 & 7.7 & 15 & 11.5 & Ref & - & 0.302 \\
\hline 2 years & 21 & 32.3 & 52 & 40.0 & 1.212 & $0.391-3.758$ & 0.740 \\
\hline First child & 39 & 60.0 & 63 & 48.5 & 1.857 & $0.626-5.513$ & 0.265 \\
\hline \multicolumn{8}{|c|}{ Previous abortion } \\
\hline No & 54 & 83.1 & 110 & 84.6 & Ref & - & \\
\hline Yes & 11 & 16.9 & 20 & 15.4 & 1.120 & $0.501-2.505$ & 0.782 \\
\hline
\end{tabular}

Previous case of stillbirth

$\begin{array}{lccccccc}\text { No } & 64 & 98.5 & 128 & 98.5 & \text { Ref } & - & \\ \text { Yes } & 1 & 1.5 & 2 & 1.5 & 1.000 & 0.089-11.236 & 1.000\end{array}$

Child's death in under 1 year

$\begin{array}{lccccccc}\text { No } & 64 & 98.5 & 126 & 96.9 & \text { Ref } & - & \\ \text { Yes } & 1 & 1.5 & 4 & 3.1 & 0.492 & 0.54-4.495 & 0.666\end{array}$

Previous premature child

$\begin{array}{lccccccc}\text { Non-premature previous child } & 25 & 38.5 & 60 & 46.2 & \text { Ref } & - & 0.218 \\ \text { Premature previous child } & 1 & 1.5 & 7 & 5.4 & 0.343 & 0.040-2.933 & 0.328 \\ \text { First child } & 39 & 60.0 & 63 & 48.5 & 1.486 & 0.804-2.746 & 0.206\end{array}$

Previous child with low birthweight

\begin{tabular}{lccccccc} 
Previous child with adequate weight & 21 & 32.3 & 63 & 48.5 & Ref & - & $0.063^{*}$ \\
Previous child with low weight & 5 & 7.7 & 4 & 3.1 & 3.750 & $0.921-15.275$ & $0.065^{*}$ \\
First child & 39 & 60.0 & 63 & 48.5 & 1.857 & $0.984-3.505$ & $0.056^{*}$ \\
\hline
\end{tabular}

\begin{tabular}{|c|c|c|c|c|c|c|c|}
\hline \multicolumn{8}{|c|}{ Section 3} \\
\hline \multicolumn{8}{|c|}{ Alcohol dependence } \\
\hline No & 58 & 89.2 & 119 & 91.5 & Ref & - & \\
\hline Yes & 7 & 10.8 & 11 & 8.5 & 1.306 & $0.481-3.543$ & 0.600 \\
\hline \multicolumn{8}{|c|}{ Smoking habit } \\
\hline No & 55 & 84.6 & 122 & 93.8 & Ref & - & \\
\hline Yes & 10 & 15.4 & 8 & 6.2 & 2.773 & $1.038-7.408$ & $0.036^{*}$ \\
\hline \multicolumn{8}{|c|}{ Drug use } \\
\hline No & 64 & 98.5 & 129 & 99.2 & Ref & - & \\
\hline Yes & 1 & 1.5 & 1 & 0.8 & 2.016 & $0.124-32.750$ & 1.000 \\
\hline \multicolumn{8}{|c|}{$\begin{array}{l}\text { Victim of violence against } \\
\text { pregnant women }\end{array}$} \\
\hline No & 57 & 87.7 & 122 & 93.8 & Ref & - & \\
\hline Yes & 8 & 12.3 & 8 & 6.2 & 2.140 & $0.765-5.990$ & $0.140^{*}$ \\
\hline \multicolumn{8}{|c|}{ Stressful event in pregnancy } \\
\hline No & 40 & 61.5 & 89 & 68.5 & Ref & - & \\
\hline Yes & 25 & 38.5 & 41 & 31.5 & 1.357 & $0.729-2.526$ & 0.335 \\
\hline
\end{tabular}

RC: odds ratio; $95 \% \mathrm{Cl}: 95 \%$ confidence interval; $p$ : level of statistical significance; Ref: reference category $* \mathrm{p}<0.20$ 
Table 3. Number of cases and controls, odds ratio, 95\% confidence interval and p-value of factors related to health care during prenatal care and childbirth (section 4).

\begin{tabular}{|c|c|c|c|c|c|c|c|}
\hline \multirow[t]{2}{*}{ Variables } & \multicolumn{2}{|c|}{$\begin{array}{c}\text { Cases } \\
(\mathrm{n}=65)\end{array}$} & \multicolumn{2}{|c|}{$\begin{array}{l}\text { Controls } \\
(n=130)\end{array}$} & \multirow[t]{2}{*}{ OR } & \multirow[t]{2}{*}{$95 \% \mathrm{Cl}$} & \multirow{2}{*}{ p } \\
\hline & $\mathbf{n}$ & $\%$ & $\mathbf{n}$ & $\%$ & & & \\
\hline \multicolumn{8}{|c|}{ Number of prenatal appointments } \\
\hline$<6$ appointments & 18 & 27.7 & 27 & 20.8 & Ref & - & \\
\hline$\geq 6$ appointments & 47 & 72.3 & 103 & 79.2 & 0.684 & $0.344-1.363$ & 0.279 \\
\hline \multicolumn{8}{|c|}{ First prenatal appointment* } \\
\hline$\leq 16$ weeks & 52 & 81.3 & 105 & 80.8 & Ref & - & \\
\hline$>16$ weeks & 12 & 18.8 & 25 & 19.2 & 0.969 & $0.451-2.082$ & 0.936 \\
\hline \multicolumn{8}{|c|}{ Pre-natal care institution* } \\
\hline Public & 54 & 84.4 & 103 & 79.2 & Ref & - & \\
\hline Private & 10 & 15.6 & 27 & 20.8 & 0.706 & $0.318-1.567$ & 0.391 \\
\hline \multicolumn{8}{|c|}{ Vaccination during pregnancy } \\
\hline No & 4 & 6.2 & 10 & 7.7 & Ref & - & \\
\hline Yes, or immunized & 61 & 93.8 & 120 & 92.3 & 1.271 & $0.383-4.218$ & 0.695 \\
\hline \multicolumn{8}{|c|}{ Residence with FHS coverage } \\
\hline No & 5 & 7.7 & 7 & 5.4 & Ref & - & \\
\hline Yes & 60 & 92.3 & 123 & 94.6 & 0.683 & $0.208-2.241$ & 0.527 \\
\hline \multicolumn{8}{|l|}{ Type of delivery } \\
\hline Vaginal & 40 & 61.5 & 89 & 68.5 & Ref & - & \\
\hline Cesarean section & 25 & 38.5 & 41 & 31.5 & 1.357 & $0.729-2.526$ & 0.335 \\
\hline
\end{tabular}

FHS: Family Health Strategy RC: odds ratio; $95 \% \mathrm{Cl}$ : 95\% confidence interval; p: level of statistical significance; Ref: reference category

* A participating puerperal woman did not perform prenatal care and was considered absent in the analysis of the data of the first prenatal and prenatal appointment.

Table 4. Number of cases and controls, odds ratio, 95\% confidence interval and p-value of factors related to maternal diseases (section 5).

\begin{tabular}{|c|c|c|c|c|c|c|c|}
\hline \multirow[t]{2}{*}{ Variables } & \multicolumn{2}{|c|}{$\begin{array}{c}\text { Cases } \\
(n=65)\end{array}$} & \multicolumn{2}{|c|}{$\begin{array}{l}\text { Controls } \\
(n=130)\end{array}$} & \multirow[t]{2}{*}{ OR } & \multirow[t]{2}{*}{$95 \% \mathrm{Cl}$} & \multirow{2}{*}{$\mathbf{p}$} \\
\hline & $\mathrm{n}$ & $\%$ & $\mathrm{n}$ & $\%$ & & & \\
\hline \multicolumn{8}{|c|}{ Gestational diabetes } \\
\hline No & 63 & 96.9 & 126 & 96.9 & Ref & - & \\
\hline Yes & 2 & 3.1 & 4 & 3.1 & 1.000 & $0.178-5.608$ & 1.000 \\
\hline \multicolumn{8}{|c|}{ Gestational hypertension } \\
\hline No & 54 & 83.1 & 114 & 87.7 & Ref & - & \\
\hline Yes & 11 & 16.9 & 16 & 12.3 & 1.451 & $0.631-3.339$ & 0.379 \\
\hline \multicolumn{8}{|c|}{ Chronic hypertension } \\
\hline No & 63 & 96.9 & 129 & 99.2 & Ref & - & \\
\hline Yes & 2 & 3.1 & 1 & 0.8 & 4.095 & $0.364-46.022$ & 0.258 \\
\hline \multicolumn{8}{|c|}{ Preeclampsia } \\
\hline No & 62 & 95.4 & 128 & 98.5 & Ref & - & \\
\hline Yes & 3 & 4.6 & 2 & 1.5 & 3.097 & $0.504-19.012$ & 0.336 \\
\hline \multicolumn{8}{|c|}{ Urinary tract infection } \\
\hline No & 37 & 56.9 & 90 & 69.2 & Ref & - & \\
\hline Yes & 28 & 43.1 & 40 & 30.8 & 1.703 & $0.919-3.153$ & $0.089 *$ \\
\hline \multicolumn{8}{|c|}{ Vaginal bleeding in the 1 st trimester } \\
\hline No & 52 & 80.0 & 115 & 88.5 & Ref & - & \\
\hline Yes & 13 & 20.0 & 15 & 11.5 & 1.917 & $0.851-4.316$ & $0.112^{*}$ \\
\hline \multicolumn{8}{|c|}{ Oligohydramnios } \\
\hline No & 62 & 95.4 & 125 & 96.2 & Ref & - & \\
\hline Yes & 3 & 4.6 & 5 & 3.8 & 1.210 & $0.280-5.226$ & 1.000 \\
\hline \multicolumn{8}{|l|}{ Anemia } \\
\hline No & 49 & 75.4 & 91 & 70.0 & Ref & - & \\
\hline Yes & 16 & 24.6 & 39 & 30.0 & 0.762 & $0.387-1.500$ & 0.431 \\
\hline \multicolumn{8}{|l|}{ Syphilis } \\
\hline No & 63 & 96.9 & 125 & 96.2 & Ref & - & \\
\hline Yes & 2 & 3.1 & 5 & 3.8 & 0.794 & $0.150-4.206$ & 1.000 \\
\hline
\end{tabular}

RC: odds ratio; $95 \% \mathrm{Cl}: 95 \%$ confidence interval; p: level of statistical significance; Ref: reference category $* \mathrm{p}<0.20$ 
Table 5. Result of logistic regression (odds ratio, 95\% confidence interval and p-value) of factors associated with low birthweight.

\begin{tabular}{|c|c|c|c|c|}
\hline Sections & Variables & OR & $95 \% \mathrm{Cl}$ & p \\
\hline \multirow{3}{*}{ Section 1} & Water consumed during pregnancy & & & \\
\hline & Mineral, from mines, wells, cisterns or the supply service of non-affected municipalities & Ref & - & \\
\hline & Supply services of affected municipalities & 2.444 & $1.203-4.965$ & $0.013^{*}$ \\
\hline \multirow{4}{*}{ Section 2} & Previous child with low birthweight & & & \\
\hline & Previous child with adequate weight & Ref & - & 0.052 \\
\hline & Previous child with low weight & 3.729 & $0.860-16.167$ & 0.079 \\
\hline & First child & 2.033 & $1.047-3.948$ & $0.036^{*}$ \\
\hline \multirow{3}{*}{ Section 3} & Smoking habit & & & \\
\hline & No & Ref & - & \\
\hline & Yes & 2.850 & $1.013-8.021$ & $0.047^{*}$ \\
\hline
\end{tabular}

RC: odds ratio; $95 \% \mathrm{Cl}$ : 95\% confidence interval; $\mathrm{p}$-value: level of statistical significance; Ref: reference category

$* p<0.05$

\section{DISCUSSION}

After the analysis adjusted for the other factors under study, we found that the higher risks of low birthweight are associated with the first children and live births whose mothers smoked during pregnancy and consumed the water supplied by the municipalities affected by the tailings from the Fundão dam failure. One of the possible explanations for the result regarding the water consumed during pregnancy may be related to the water pollution of Rio Doce caused by one of the greatest socio-environmental tragedies in the country. On November 5, 2015, in Mariana, Minas Gerais, more than 70 million cubic meters of iron ore tailings sludge leaked after a Samarco dam collapsed, a joint venture of Brazil's Vale and Anglo-Australian BHP Billiton ${ }^{11}$. In addition to destroying villages, the mud traveled $663 \mathrm{~km}$ along the rivers Doce, Gualaxo do Norte and Carmo, reaching 35 municipalities in Minas Gerais and four in Espírito Santo ${ }^{11,12}$.

According to Wanderley et al. ${ }^{12}$, recent studies have presented varied evidence on the presence of heavy metals in the river and previous studies have already shown the contamination of the river by metals, due to mineral processing in the upper Rio Doce. The presence of these metals puts the population's long-term health at risk, with the possibility of a considerable increase in chronic disease ${ }^{12}$. Many questions are still being raised about what levels of contamination and health effects are present and expected in the exposed population, especially in soil and water quality for human consumption ${ }^{11}$. The population of Governador Valadares seems to fear the contamination of the water of the Rio Doce, which was once again supplied for human consumption. This situation may explain the fact that almost $40 \%$ of the families participating in this study still use mineral water for consumption, two to three years after the disaster. Financial expenses with the purchase of mineral water aggravate the situation, since the population studied presented predominantly low economic level, with monthly family income less than two minimum wages.

Newborns whose mothers, during pregnancy, consumed water provided by municipalities affected by the mud had a higher risk of low birthweight compared to those whose mothers consumed mineral water, from wells, mines, cisterns or supplied by unaffected municipalities. Bezerra ${ }^{13}$ evaluated the concentration of some metals in the water available for consumption in Governador Valadares, through the analysis of samples from five collection points, and compared it with the specific legislation on potability. According to the results, there were elevated levels of aluminum, selenium and antimony in the samples, making the water unfit for consumption according to the potability criterion.

Public authorities of the state of Minas Gerais evaluated the quality of water distributed by the supply service of Governador Valadares to residents of several neighborhoods of the city. 
The results of the analyses, carried out in 2016, showed that no toxic and harmful metals were detected at concentrations higher than potability standards. However, aluminum presented concentrations above the limits established by the Consolidation Ordinance of the Ministry of Health No. 5, of September 28, 2017. In addition, at some collection points, the total coliform and turbidity parameters of the water did not meet the potability criteria ${ }^{14}$. Considering that dam tailings have high concentrations of aluminum in their composition, it is possible that this metal was transported along the Rio Doce, causing changes in the chemical composition in various stretches of the watercourse, according to the direction of the winds, rainfall indices and river flow. In addition, it was found in the evaluation that only aluminum sulfate has been used as a coagulant for water treatment, and the use of the black acacia polymer was interrupted ${ }^{14,15}$. Aluminum salts are widely used as coagulants in the drinking water treatment process; however, its use may increase the concentration of this metal in treated waters ${ }^{16}$. Thus, the presence of residual aluminum concentrations detected in the water intended for the supply of the population may have as its origin not only the existence of this element in the uptake, but also in the use of coagulant based on aluminum salts, in the treatment process and in the operating conditions of the water treatment plant ${ }^{14,15}$.

The mother's environment has implications for the health of the fetus, which is transplacentally exposed to contaminants present in food, water and air ${ }^{17}$. Some contaminants can harm both the mother and fetus, such as aluminum. Humans are naturally exposed to aluminum through drinking water, food, medicines, dust, hygiene products or cooking utensils ${ }^{17}$. Despite the knowledge about aluminum toxicity, little is known about its effects in humans, and most studies are conducted in models with laboratory animals. It is known, however, that fetuses, newborns and developing infants, due to their immaturity, are more vulnerable to the toxicity of exposure to this metal ${ }^{18,19}$.

A study conducted to evaluate the effect of exposure to aluminum, administered in drinking water, in rats during pregnancy, lactation and post-weaning, observed that rats exposed to this component gained less weight during pregnancy and consumed less water and food during the lactation period, and their offspring had decreased body weight in comparison to the control group ${ }^{20}$. Aluminum ingested during pregnancy also affects the metabolism of essential elements such as calcium, magnesium, manganese, copper, zinc and iron ${ }^{19}$. A study conducted with pregnant rats treated with aluminum showed that oral exposure to this metal during pregnancy can produce significant changes in the tissue distribution of several essential elements, with possible consequences on the metabolism of the fetus ${ }^{21}$.

Another explanation for the results is the possibility of pesticides in the water consumed by the population. Data from the Ministry of Health and the Human Consumption Water Quality Surveillance Information System show that different pesticides were found in the water of 25\% of municipalities in Brazil between 2014 and 2017. Twenty-seven types of pesticides were tested, 16 of which are classified as highly toxic and 11 are associated with diseases such as fetal malformation and cancer. In Governador Valadares, 27 pesticides were detected in the water that supplies the population, but none with concentration higher than that allowed by Brazilian legislation. However, 24 of these pesticides are concentrated above the safe limit set by the European Union ${ }^{22}$. One of them was atrazine, which is present as a mixture in drinking water, groundwater and surface water and can alter fetal growth. A cohort study conducted in France evaluated the association between atrazine exposure during pregnancy and adverse effects at birth, using urine samples, and found a relationship with fetal growth restriction ( $\mathrm{OR}=1.5$; 95\% confidence interval $[95 \% \mathrm{CI}]=1.0-2.2)$. The authors point out that atrazine was banned in Europe and that the study shows the persistence of this component in the environment, alerting countries in which it is still in use, such as Brazil, the United States, Argentina, Mexico and China ${ }^{23}$.

Newborns who were the first children of their mothers had a higher risk of low birthweight compared with those whose mothers had previous children with adequate weight. The biological mechanisms of how parity can influence the incidence of low birthweight is 
not yet well known. A systematic review and meta-analysis that investigated the risks in pregnancy for the different parities found a significant reduction (280 grams) in birthweight in first children in relation to women who have already had two to four other births ${ }^{24}$. A study conducted in Indonesia detected a 46\% higher risk $(\mathrm{OR}=1.46 ; \mathrm{p}=0.030)$ of having children with low birthweight in women pregnant for the first time compared with those who had one previous pregnancy ${ }^{25}$. The low birthweight rate tends to be higher in the first child than in the second and third ${ }^{26}$. This can be explained by the fact that maturation of uterine structures occur in the first pregnancy, which improves their conditions and allows for greater placental development and better fetal nutrition ${ }^{27}$.

Smoking during pregnancy is also noteworthy as it presents risks to the newborn. A systematic review and meta-analysis investigated the relationship between maternal smoking and low birthweight and found that pregnant smokers were twice as likely to have a child with the condition when compared with nonsmokers ${ }^{28}$. Zhang et al. ${ }^{29}$ found that infants whose mothers smoked during pregnancy had the three anthropometric measurements at birth (weight, head circumference, and length) reduced. In view of the high prevalence and adverse effects on fetal nervous system development and infant morbidity and mortality, it is necessary to intervene in order to reduce smoking among pregnant women. As the gestational period is the most appropriate to encourage smoking cessation, its harmful effects on the health of pregnant women and the fetus should be reinforced in prenatal appointments by the health team more intensely and repeatedly ${ }^{30}$.

One of the limitations of this study is the sample size. However, all mothers of live births who met the inclusion criteria were invited to participate. The greatest difficulty was due to the pairing criteria adopted. Pairing by sex was necessary due to greater vulnerability and association with perinatal and neonatal mortality in boys ${ }^{31}$. In addition, the literature reports a higher risk of low birthweight in girls ${ }^{25}$, in agreement with what was found in this study, as $50.8 \%$ of newborns were girls. Pairing through date of birth was conducted to make the sample as similar as possible regarding perinatal assistance, including human resources and professional qualification of the working staff.

Another limitation is that this study did not assess water quality, using only information about the type of water consumed during pregnancy. To this moment, few were the publications that assess the quality of the water consumed by the population of Governador Valadares and neighboring municipalities ${ }^{13,15}$, which hinders general results. Furthermore, there are no studies in the region previous to the disaster, which makes it impossible to state that it was responsible for the contamination profile observed ${ }^{12,32}$ Finally, we did not assess the exposure of pregnant women to the aluminum in food, air, kitchen utensils and hygiene items and thus we could not make sure that the metal was present only in the consumed water.

We can conclude among the analyzed factors that water consumed during pregnancy, first pregnancy and smoking habits presented association with low birthweight in the study population. We reinforce the importance of epidemiological studies that assess water quality and its hazards, as well as the need to greater control in the prenatal period of women pregnant for the first time and greater support of anti-smoking policies, specially during pregnancy. Further studies in the field are needed, as well as the periodic assessment of water quality.

\section{REFERENCES}

1. González-Jiménez J, Rocha-Buelvas A. Risk factors associated with low birth weight in the Americas : literature review. Rev Fac Med Univ Nac Colomb. 2018;66(2):255-60. https://doi.org/10.15446/revfacmed.v66n2.61577

2. United Nations Children's Fund; World Health Organization. Low birthweight: country, regional and global estimates. New York: UNICEF; 2004. 
3. Fondo de las Naciones Unidas para la Infancia. Examen estadístico de un mundo apropiado para los niños y las niñas. Nueva York: UNICEF; 2007. (Progreso para la infancia, 6).

4. Buriol VCS, Hirakata V, Goldani MZ, Silva CH. Temporal evolution of the risk factors associated with low birth weight rates in Brazilian capitals (1996-2011). Popul Health Metr. 2016;14:15 https://doi.org/10.1186/s12963-016-0086-0

5. Leal MC, Szwarcwald CL, Almeida PVB, Aquino EML, Barreto MC, Barros $\mathrm{F}$, et al. Reproductive, maternal, neonatal and child health in the 30 years since the creation of the Unified Health System (SUS). Cienc Saude Coletiva. 2018;23(6):1915-28. https://doi.org/10.1590/1413-81232018236.03942018

6. Slovic AD, Diniz CS, Ribeiro H. Clean air matters: an overview of trafficrelated air pollution and pregnancy. Rev Saude Publica. 2017;51:5. https://doi.org/10.1590/s1518-8787.2017051006652

7. Gouveia N, Bremner SA, Novaes HMD. Association between ambient air pollution and birth weight in São Paulo, Brazil. J Epidemiol Community Health. 2004;58(1):11-7. https://doi.org/10.1136/jech.58.1.11

8. Ministério da Saúde (BR). Programa Humanização do Parto: humanização do pré-natal e nascimento. Brasília (DF); 2002 [cited 2019 Out 19]. Available from: http://bvsms.saude.gov.br/bvs/publicacoes/parto.pdf

9. Viellas EF, Domingues RMSM, Dias MAB, Gama SGN, Theme-Filha MM, Costa JV, et al. Assistência pré-natal no Brasil. Cad Saude Publica. 2014;30 Supl 1:S85-100. https://doi.org/10.1590/0102-311X00126013

10. Mayfield D, McLeod G, Hall P. The CAGE Questionnaire: validation of a new alcoholism screening instrument. Am J Psychiatry. 1974;131(10):1121-3. https://doi.org/10.1176/ajp.131.10.1121

11. Porto MFS. A tragédia da mineração e do desenvolvimento no Brasil: desafios para a saúde coletiva. Cad Saude Publica. 2016;32(2):e00211015. https://doi.org/10.1590/0102-311X00211015

12. Wanderley LJ, Mansur MS, Milanez B, Pinto RG. Desastre da Samarco/Vale/BHP no Vale do Rio Doce: aspectos econômicos, políticos e socio ambientais. Cienc Cult. 2016;68(3):30-5. https://doi.org/10.21800/2317-66602016000300011

13. Bezerra ES. Determinação de metais na água disponibilizada para consumo humano no município de Governador Valadares - MG. Brasília, DF: Universidade de Brasília, Faculdade de Ceilândia; 2016. Trabalho de Conclusão de Curso (graduação) de Farmácia.

14. Diniz PS. Inquérito civil $n^{\circ} 0105.15 .002048-2$. Qualidade da água no município de Governador Valadares após o desastre ambiental causado pelo rompimento da barragem da Samarco Mineração S/A. Belo Horizonte: Ministério Público do Estado de Minas Gerais; Procuradoria Geral de Justiça; 2016. (Laudo IDCEAT 26935311).

15. Diniz PS. Requerimento de apoio técnico formulado pelas $10^{\mathrm{a}}$ e $14^{\mathrm{a}}$ Promotorias de Justiça da Comarca de Governador Valadares. Belo Horizonte: Ministério Público do Estado de Minas Gerais; Procuradoria Geral de Justiça; 2018. (Laudo SISCEAT32636944).

16. Wang W, Yang H, Wang X, Jiang J, Zhu W. Effects of fulvic acid and humic acid on aluminum speciation in drinking water. J Environ Sci. 2010;22(2):211-7. https://doi.org/10.1016/S1001-0742(09)60095-4

17. Katic J, Fucic A, Gamulin M. Prenatal, early life, and childhood exposure to genotoxicants in the living environment. Arch Ind Hyg Toxicol. 2010;61(4):455-64. https://doi.org/10.2478/10004-1254-61-2010-2065

18. Röllin HB, Nogueira C, Olutola B, Channa K, Odland J. Prenatal exposure to aluminum and status of selected essential trace elements in rural South African women at delivery. Int J Environ Res Public Health. 2018;15(7):1494. https://doi.org/10.3390/ijerph15071494

19. Fanni D, Ambu R, Gerosa C, Nemolato S, lacovidou N, Van Eyken P, et al. Aluminum exposure and toxicity in neonates: a practical guide to halt aluminum overload in the prenatal and perinatal periods. World J Pediatr. 2014;10(2):101-7. https://doi.org/10.1007/s12519-014-0477-x

20. Colomina MT, Roig JL, Torrente M, Vicens P, Domingo JL. Concurrent exposure to aluminum and stress during pregnancy in rats: effects on postnatal development and behavior of the offspring. Neurotoxicol Teratol. 2005;27(4):565-74. https://doi.org/10.1016/j.ntt.2005.06.014

21. Bellés M, Albina ML, Sanchez DJ, Corbella J, Domingo JL. Effects of oral aluminum on essential trace elements metabolism during pregnancy. Biol Trace Elem Res. 2001;79(1):67-81. https://doi.org/10.1385/BTER:79:1:67 
22. Aranha A, Rocha L. 1 em 4 municípios tem "coquetel" com agrotóxicos na água. Exame. 2019 Apr 17 [updated 2019 Jun 13; cited 2019 Jun 15]. Available from: https://exame.abril.com. br/brasil/1-em-4-municipios-tem-coquetel-com-agrotoxicos-na-agua-consulte-o-seu/

23. Chevrier C, Limon G, Monfort C, Rouget F, Garlantézec R, Petit C, et al. Urinary biomarkers of prenatal atrazine exposure and adverse birth outcomes in the PELAGIE Birth Cohort. Environ Health Perspect. 2011;119(7):1034-41. https://doi.org/10.1289/ehp.1002775

24. Shah SS; Knowledge Synthesis Group on Determinants of LBW/PT Births. Parity and low birth weight and preterm birth: a systematic review and meta-analyses. Acta Obstet Gynecol Scand. 2010;89(7):862-75. https://doi.org/10.3109/00016349.2010.486827

25. Andayasari L, Opitasari C. Parity and risk of low birth weight infant in full term pregnancy. Health Sci J Indones. 2016;7(1):13-6. https://doi.org/10.22435/hsji.v7i1.4701.13-16

26. Oh Y, Bae J. Impact of changes in maternal age and parity distribution on the increasing trends in the low birth weight and very low birth weight rates in South Korea, 2005-2015. J Prev Med Public Health. 2019;52(2):123-30. https://doi.org/10.3961/jpmph.18.247

27. Valero de Bernabé J, Soriano T, Albaladejo R, Juarranz M, Calle ME, Martínez D, et al. Risk factors for low birth weight: a review. Eur J Obstet Gynecol Reprod Biol. 2004;116(1):3-15. https://doi.org/10.1016/j.ejogrb.2004.03.007

28. Pereira PPS, Mata FAF, Figueiredo ACG, Andrade KRC, Pereira MG. Maternal active smoking during pregnancy and low birth weight in the Americas: a systematic review and meta-analysis. Nicotine Tob Res. 2017;19(5):497-505. https://doi.org/10.1093/ntr/ntw228

29. Zhang L, González-Chica DA, Cesar JA, Mendoza-Sassi RA, Beskow B, Larentis N, et al. Tabagismo materno durante a gestação e medidas antropométricas do recém-nascido: um estudo de base populacional no extremo sul do Brasil. Cad Saude Publica. 2011;27(9):1768-76. https://doi.org/10.1590/S0102-311X2011000900010

30. Dias-Damé JL, Lindsay AC, Cesar JA. Cessação do tabagismo na gestação: estudo de base populacional. Rev Saude Publica. 2019;53:3. https://doi.org/10.11606/S1518-8787.2019053000619

31. Chiavegatto Filho ADP, Laurenti R. O sexo masculino vulnerável: razão de masculinidade entre os óbitos fetais brasileiros. Cad Saude Publica. 2012;28(4):720-8. https://doi.org/10.1590/S0102-311X2012000400011.

32. Carvalho GO, Pinheiro ADA, Sousa DM, Padilha JA, Souza JS, Galvão PM, et al. Metals and arsenic in water supply for riverine communities affected by the largest environmental disaster in Brazil: The Dam Collapse on Doce River. Orbital Electron J Chem. 2018;10(4 Spec No). http://dx.doi.org/10.17807/orbitalv10i4.1081

Funding: Coordenação de Aperfeiçoamento de Pessoal de Nivel Superior - Brazil (CAPES) - Funding Code 001; PROQUALI Program of the Universidade Federal de Juiz de Fora (doctoral scholarship granted to the first author during the study).

Author's Contribution: Study design and planning: ECD, PSCC, LCR. Data collection, analysis and interpretation: ECD, PSCC, APN, LCR. Manuscript development or review: ECD, PSCC, APN, LCR. Approval of the final version: ECD, PSCC, APN, LCR. Public responsibility for the content of the article: ECD, PSCC, APN, LCR.

Conflict of Interest: The authors declare no conflict of interest. 